\title{
THE PRICE EVOLUTION IN THE CONTEXT OF ECONOMIC CRISIS
}

\author{
Doriana Andreea Rămescu ${ }^{1 *}$, Nicoleta Sîrghi ${ }^{2}$ \\ 1,2 Department of Economics and Business Modelling, Faculty of Economics and Business \\ Administration, West University of Timisoara, Timisoara, Romania \\ doriana.ramescu@e-uvt.ro \\ nicoleta.sirghi@e-uvt.ro
}

\begin{abstract}
The economic crisis is a negative macroeconomic phenomenon with consequences both at European Union level and worldwide. The main objective of this paper is to analyse the variation of price levels in Romania, during the economic crisis until the end of 2015, compared with the Member States of the European Union and the countries of the European Free Trade Association. For this research, information provided by EUROSTAT was used, such as price level indices for actual individual consumption per capita, and for different goods and services, calculated based on purchasing power parity. The aim is to identify solutions to rising living standards, compared with more developed countries of the European Union. This paper presents possible solutions for avoiding a future economic crisis, caused by overconsumption. The paper is divided into four sections: introduction, part two which presents aspects of the economic crisis in Romania and in the European Union, the third part presents price level indices for different products and services in 2015, and the last part, the conclusions of the research.
\end{abstract}

Keywords: Economic crisis, Price level, Consumption, Purchasing power parity.

JEL classification: E37, E31, E29, C32.

\section{Introduction}

One of the distinctive features of the economic crisis was a sudden collapse of credit on a global level, as banks stopped lending to each other, in fear of unknown and uncertain exposure to toxic debts (Roubini, Mihm, 2010). This effect was also experienced in South East Europe where a sudden stop in credit growth struck almost all the countries at the same time (Bartlett, Prica, 2012). The economic crisis that Romania has gone through was mainly a domestic crisis, caused by the wrong mix of macroeconomic policies taken in the recent years. Economic growth proved to be one of the unhealthy natures, and that's because Romania had in those years an economical growth based on excessive consumption financed by debt. (Donath, Cismaş, 2009). This state of affairs is valid for the government, for companies and for the population.

In this paper, we aim to analyse the impact of economic crisis on the economy and price levels for consumer goods and services in Romania and the European Union (EU). We focus on price level indices (PLIs) which offer a comparison of price levels between countries in relation with the EU average, calculated based on purchasing power parity. The price levels for the following consumer goods are analysed: food and non-alcoholic beverages, alcoholic beverages and tobacco, clothing and footwear; and for the following services: water, electricity, gas and other fuels, health and education.

\footnotetext{
* Corresponding author
} 


\section{Aspects of the Economic Crisis in Romania and in the European Union Countries} In economics, purchasing power parity (PPP) is a method used to calculate an alternative exchange rate between the currencies of two countries. PPP measure the purchasing power of a coin in an international measure unit (usually dollars) because goods and services have different prices in some countries than others. The exchange rates of the PPP are used to compare living standards in different countries. Gross domestic product (GDP) of a country is measured initially in local currency, so any comparison between the two countries requires convertible currencies. Comparisons based on nominal exchange rates are considered unrealistic, not reflecting these price differences between countries.

Differences between PPP and nominal exchange rates can be significant. Although GDP per capita is often used as an indicator of countries' level of welfare, it is not necessarily an appropriate indicator of the actual standard of living of households. For the latter purpose, a better indicator may be actual individual consumption (AIC) per capita. (Cismaş, Pitorac, 2013).

Actual individual consumption (AIC) consists of goods and services consumed by individuals, regardless if goods and services are purchased and paid by households, by government or non-profit institutions. Summing up actual individual consumption implies all goods and services consumed by households. In making international comparisons, AIC is often considered to be the most appropriate measures. (Gerstberger, Yaneva, 2013).

Price level indices (PLIs) provide a comparison of price levels between countries in relation to the EU average: if the PLI is higher than 100 , the country concerned is relatively more expensive than the EU average, while if the PLI is less than 100, the country is relatively cheaper than the EU average.

The EU average is calculated as the weighted average of the national PLIs, weighted by the expenditures corrected for price level differences. In this paper we will analyse only PLIs for AIC, because they cover only goods and services consumed by households and are closer to the concept of price levels that most people are familiar with, unlike an indicator of the level of prices based on GDP.

We analyse fluctuations in PLIs in Romania compared to other EU countries and the EU average, and the impact that the economic crisis has had on them (Table no.1).

Table 1 shows the PLIs for AIC of households for the whole period 2008 - 2015, in Romania, compared to the countries with the highest living standards in the EU and in relation with the EU 28 average.

Table 1: Price level indices (EU28 = 100), Actual individual consumption

\begin{tabular}{|c|c|c|c|c|c|c|c|c|}
\hline Geo/Year & $\mathbf{2 0 0 8}$ & $\mathbf{2 0 0 9}$ & $\mathbf{2 0 1 0}$ & $\mathbf{2 0 1 1}$ & $\mathbf{2 0 1 2}$ & $\mathbf{2 0 1 3}$ & $\mathbf{2 0 1 4}$ & $\mathbf{2 0 1 5}$ \\
\hline Denmark & 143.1 & 146.3 & 144.6 & 142.7 & 140.6 & 139.7 & 139.5 & 137.1 \\
\hline EU 28 & 100 & 100 & 100 & 100 & 100 & 100 & 100 & 100 \\
\hline Finland & 120.3 & 123.7 & 122.5 & 123.1 & 122.4 & 124.5 & 123.9 & 121.2 \\
\hline Iceland & 106.2 & 99.3 & 106.6 & 108.5 & 111.9 & 113.8 & 121.1 & 129.4 \\
\hline Norway & 146.5 & 144.5 & 157.5 & 164.2 & 173.0 & 167.3 & 157.9 & 147.9 \\
\hline Romania & 56.0 & 50.9 & 50.1 & 49.3 & 46.2 & 48.4 & 48.0 & 47.0 \\
\hline Sweden & 118.1 & 111.9 & 125.6 & 132.4 & 135.5 & 142.3 & 135.8 & 131.2 \\
\hline Switzerland & 131.4 & 140.4 & 152.5 & 166.1 & 161.5 & 155.9 & 156.3 & 171.3 \\
\hline
\end{tabular}

Source: http://appsso.eurostat.ec.europa.eu/nui/submitViewTableAction.do

Denmark had in 2008 the highest price levels from the EU Member States analysed, 43\% above the EU 28 average. It rose by $3 \%$ in 2009, and then began to drop, reaching a price level of $37 \%$ above the average EU 28 at the end of 2015 . Although the price level declined 
by $6 \%$ from 2008 to the end of 2015 , Denmark is the country with the highest price levels from EU Member States, surpassed only by the EFTA States.

Norway had in 2008 the highest price levels, 46\% above the average EU 28, which increased during the economic crisis, reaching $73 \%$ above the EU 28 average in 2012. After 2012 the price levels began to drop at around 48\% above the EU 28 at the end of 2015.

Switzerland had, in 2008, a price level of 31\% above the EU 28 average, which has increased over the years, reaching $66 \%$ in 2011 . After a slight decrease in the crisis period, Switzerland is today the country with the highest price levels, about $72 \%$ above the average EU 28 at the end of 2015.

Sweden had, in 2008, a price level of $18 \%$ above the EU 28 average, which has increased over the years, reaching its highest point in 2013, meaning $42 \%$ above the EU average. Even though price level indices decreased in the following two years, Sweden remains one of the countries with the highest price level indices in the European Union, with $31 \%$ above the EU 28 average in 2015, 13\% higher than 2008.

Finland is one of the countries with the most constant price level indices from the ones analysed. It had, in 2008, a price level of $20 \%$ above the EU 28 average, remaining constant at $22 \%-24 \%$ above the EU average during 2009-2014 period, and dropping to $21 \%$ in 2015 . Romania had in 2008 a price level of $44 \%$ below the EU 28 average, which fell in 2009 by about $6 \%$ and continued to fall, reaching by the end of 2015, 53\% below the EU 28 average. Denmark has a price level almost three times higher than Romania, while Switzerland has a price level almost four times higher than Romania. This shows that price dispersion between EU Member States remains significant despite close economic integration.

In Figure 1 we can see, graphically, the fluctuation of PLIs for the whole period 2008-2015, for the countries analysed above, and the relation between Romania and EU 28 average.

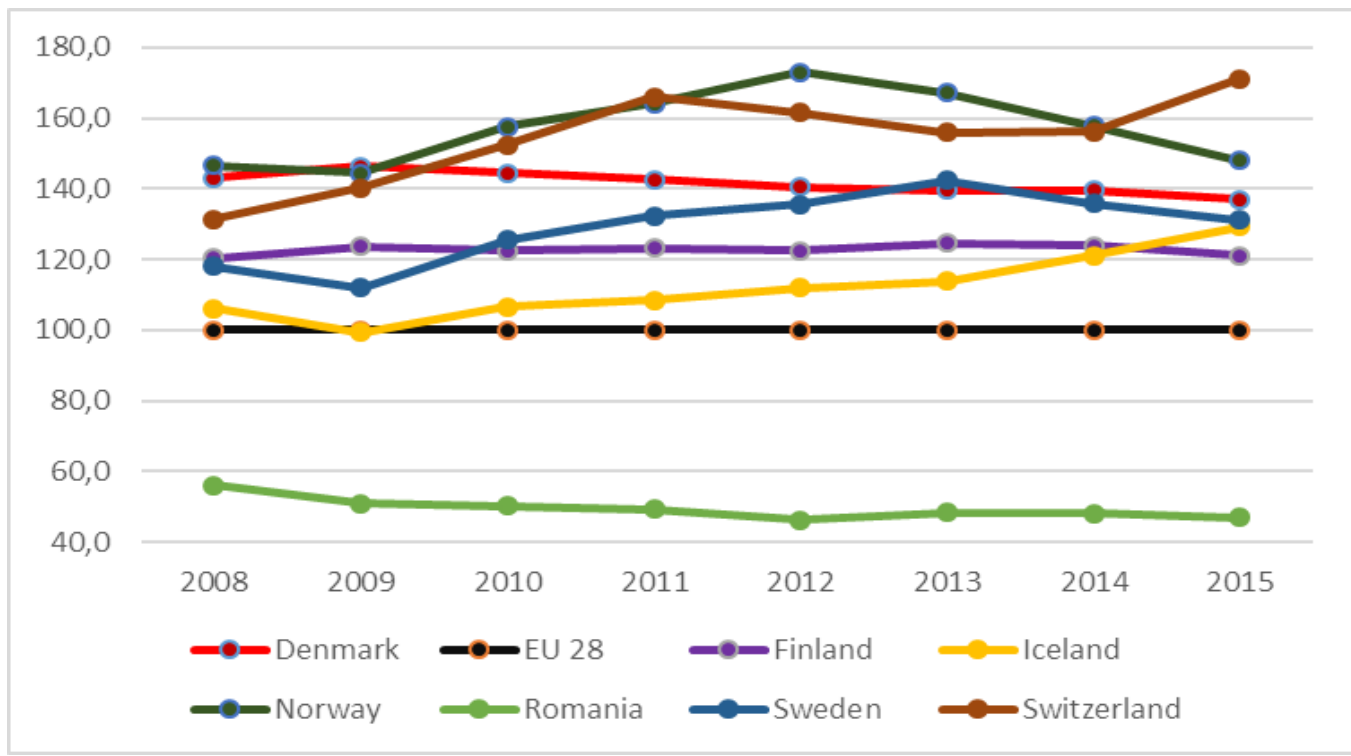

Figure 1: Price level indices for Actual Individual Consumption

Source: http://appsso.eurostat.ec.europa.eu/nui/submitViewTableAction.do

Table 2 shows the PLIs for AIC of households for the whole period 2008 - 2015, in Romania, compared to the countries with the lowest living standards in the EU and in relation with the EU 28 average. 
Table 2: Price level indices (EU28 = 100), Actual individual consumption

\begin{tabular}{|l|c|c|c|c|c|c|c|c|}
\hline Geo/Year & $\mathbf{2 0 0 8}$ & $\mathbf{2 0 0 9}$ & $\mathbf{2 0 1 0}$ & $\mathbf{2 0 1 1}$ & $\mathbf{2 0 1 2}$ & $\mathbf{2 0 1 3}$ & $\mathbf{2 0 1 4}$ & $\mathbf{2 0 1 5}$ \\
\hline Bulgaria & 43.5 & 45.1 & 44.1 & 44.8 & 44.8 & 43.9 & 42.9 & 41.9 \\
\hline Croatia & 69.6 & 71.6 & 71.3 & 68.2 & 65.8 & 64.9 & 62.6 & 62.0 \\
\hline EU 28 & 100 & 100 & 100 & 100 & 100 & 100 & 100 & 100 \\
\hline Greece & 90.4 & 93.4 & 92.3 & 92.3 & 88.5 & 84.1 & 81.7 & 79.7 \\
\hline Hungary & 64.1 & 57.9 & 57.1 & 56.3 & 55.5 & 54.7 & 53.2 & 53.0 \\
\hline Poland & 63.9 & 53.7 & 55.9 & 54.5 & 52.6 & 52.8 & 52.6 & 51.7 \\
\hline Romania & 56.0 & 50.9 & 50.1 & 49.3 & 46.2 & 48.4 & 48.0 & 47.0 \\
\hline
\end{tabular}

Source: http://appsso.eurostat.ec.europa.eu/nui/submitViewTableAction.do

Bulgaria had in 2008 the lowest PLIs from the EU Member States analysed, 56\% below the EU 28 average. It rose by $1.5 \%$ in 2009 , and then began to drop, reaching a price level of $58 \%$ below the EU 28 average at the end of 2015. Throughout the whole period analysed, from 2008 to the end of 2015, Bulgaria was and continues to be the country with the lowest PLIs from EU Member States.

A particular case is Croatia which joined the European Union in 2013, six years later than Romania and Bulgaria. It had in 2008 a price level of $30 \%$ below the EU 28 average, which rose in 2009 by $2 \%$ and then began to drop continuously. Even after joining the European Union, in 2013 the price levels continued to drop, reaching by the end of $2015,48 \%$ below the EU 28 average.

Romania had in 2008 a price level of $44 \%$ below the EU 28 average, which fell in 2009 by about $6 \%$ and continued to fall, reaching by the end of $2015,53 \%$ below the EU 28 average. As seen from the above table, Romania is the second country with the lowest living standards in the EU, surpassing only Bulgaria, with price levels at almost half the EU average.

Greece was so affected by the economic crisis that only two situations were possible: exclusion from the European Union or annulment of part of the debt and reorganization of the rest, which was adopted after long negotiations. Greece had in 2008 a price level of $9.6 \%$ below the EU 28 average, which rose in 2009 by $3 \%$ and then continued to drop, reaching by the end of $2015,20 \%$ below the EU 28 average. Even though Greece's price levels have always been below the EU 28 average and with all the economic difficulties she faced, Greece still has a price level almost two times higher than Bulgaria, and above all other countries analysed in the table above.

In Figure 2 we can see, graphically, the fluctuation of PLIs for the whole period 2008-2015, for the countries analysed above, and the relation between Romania and EU 28 average. 


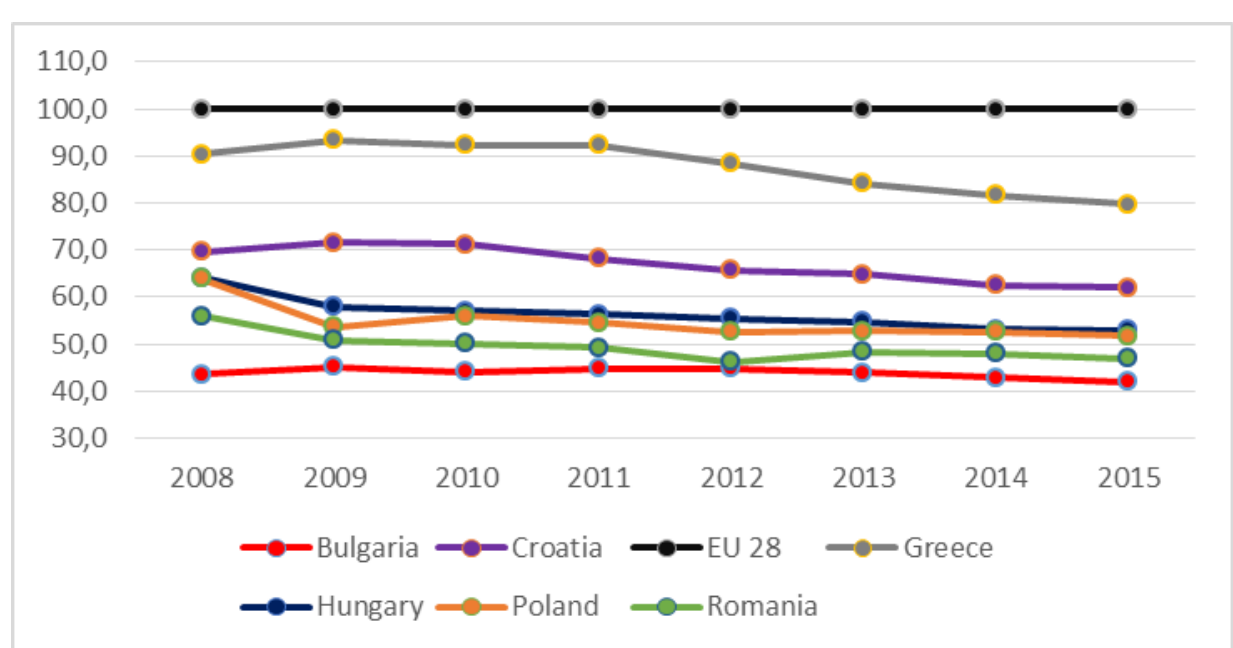

Figure 2: Price level indices for Actual Individual Consumption

Source:http://appsso.eurostat.ec.europa.eu/nui/submitViewTableAction.do

\section{Price Level Indices for Different Products and Services}

In this section, we will analyse the price level indices for different and essential goods and services in the European Union in 2015. Observing the price differences is important to analyse the development of the EU market for goods and services.

Table 3 shows the PLIs for different products in 2015, in Romania, compared to the countries with the highest and lowest living standards in the EU and in relation with the EU 28 average. We will analyse PLIs for food and non-alcoholic beverages, alcoholic beverages and tobacco and clothing and footwear.

Table 3: Price level indices for 2015 (EU28 = 100)

\begin{tabular}{|c|c|c|c|}
\hline Geo/products & $\begin{array}{c}\text { Food and non-alcoholic } \\
\text { beverages }\end{array}$ & $\begin{array}{c}\text { Alcoholic beverages } \\
\text { and tobacco }\end{array}$ & $\begin{array}{c}\text { Clothing and } \\
\text { footwear }\end{array}$ \\
\hline Bulgaria & 69.6 & 55.1 & 77.1 \\
\hline Croatia & 91.1 & 70.1 & 93.3 \\
\hline Denmark & 144.6 & 118.9 & 132.6 \\
\hline EU 28 & 100 & 100 & 100 \\
\hline Finland & 119.4 & 131.8 & 121.4 \\
\hline Greece & 103.2 & 89 & 99 \\
\hline Hungary & 78.9 & 65.3 & 83.2 \\
\hline Iceland & 129.7 & 173.2 & 153.1 \\
\hline Norway & 159.2 & 221.4 & 92.7 \\
\hline Poland & 62.5 & 69.4 & 88.8 \\
\hline Romania & 63.7 & 68.7 & 128.7 \\
\hline Sweden & 123.6 & 126.4 & 131.3 \\
\hline Switzerland & 173.2 & 129.3 & 9 \\
\hline
\end{tabular}

Source: http://appsso.eurostat.ec.europa.eu/nui/show.do?dataset=prc ppp ind\&lang=en 
Switzerland has the highest price levels for food and non-alcoholic beverages, $73 \%$ above the EU 28average, followed by Norway with 59\%above the EU 28average. The lowest price levels are in Poland, 37\% below the EU 28 average and Romania, 36\% below the EU 28 average.

For alcoholic beverages and tobacco, Norway has by far the highest price level indices, with $122 \%$ above the EU 28 average, followed by Iceland with $73 \%$ above the EU 20 average and Finland with almost $32 \%$ above the EU average.

Bulgaria has the lowest price level indices, with $45 \%$ below the EU 28 average, followed by Hungary with $35 \%$ below the EU average. As we can see Norway has a price level four times higher than Bulgaria on alcoholic beverages and tobacco.

Bulgaria has also the lowest PLIs on clothing and footwear, $23 \%$ below the EU 28 average, while Icelanders pay the highest price on clothing and footwear, with $53 \%$ above the EU 28 average.

Romania has some of the lowest price levels among the EU Member States with PLIs of $36 \%$ below the EU 28 average on food and non-alcoholic beverages and $31 \%$ below the EU average on alcoholic beverages and tobacco. On clothing and footwear Romanians pay $11 \%$ below the EU average, surpassing Bulgaria with $23 \%$ and Hungary with $17 \%$ below the EU average. The highest price differences are in alcoholic beverages and tobacco due to tax differences of these products among the Member States, while price dispersion is lower on clothing and footwear.

In Figure 3 we can see, graphically, the fluctuation of PLIs in 2015, for the countries analysed above, and the relation between Romania and the EU 28 average.

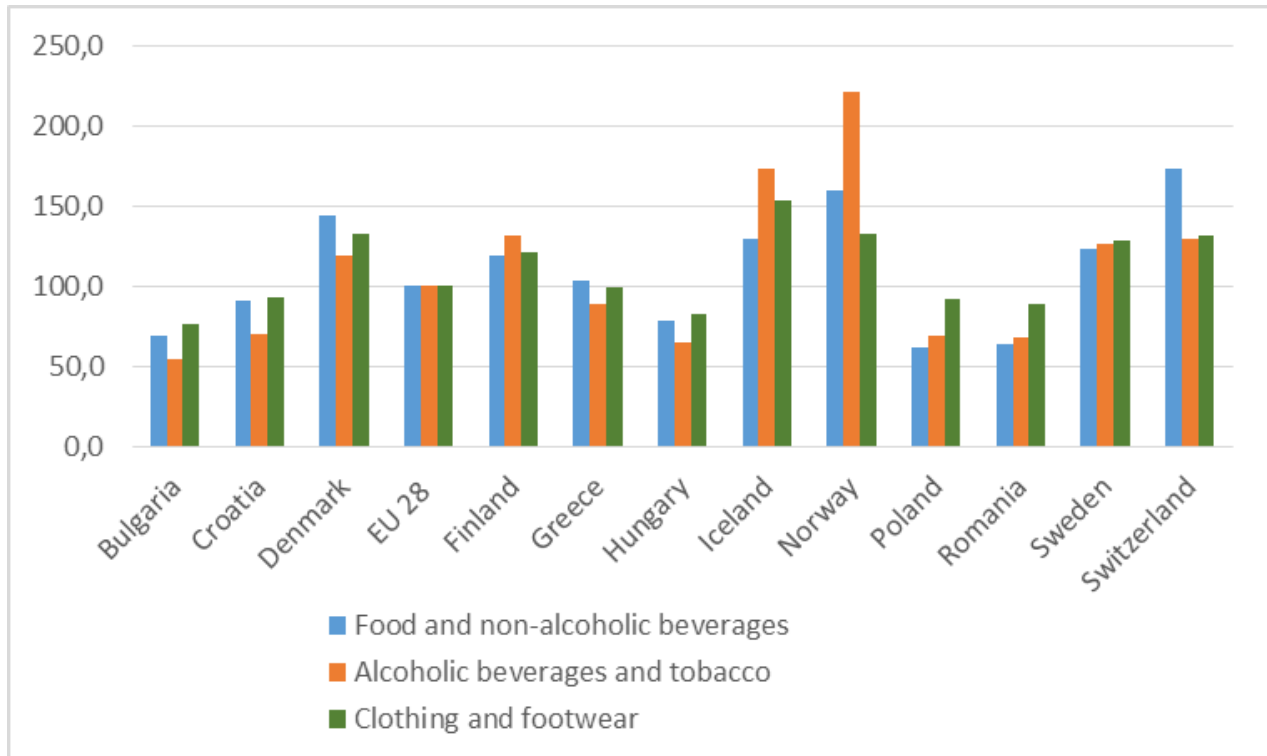

Figure 3: Price level indices for different products in 2015

Source: http://appsso.eurostat.ec.europa.eu/nui/submitViewTableAction.do

Table 4 shows the PLIs for different services (water, electricity, gas and other fuels, health and education) in 2015, in Romania, compared to the countries with the highest and lowest living standards in the European Union. 
Table 4: Price level indices for $2015(E U 28=100)$

\begin{tabular}{|l|c|c|c|}
\hline \multicolumn{1}{|c|}{ Geo/Services } & $\begin{array}{c}\text { Water, electricity, gas } \\
\text { and other fuels }\end{array}$ & Health & Education \\
\hline Bulgaria & 29 & 27.3 & 20 \\
\hline Croatia & 43.6 & 52.1 & 45.7 \\
\hline Denmark & 146.9 & 134.8 & 148.2 \\
\hline EU 28 & 100 & 100 & 100 \\
\hline Finland & 128.2 & 131.4 & 124.2 \\
\hline Greece & 69.8 & 66.5 & 70.7 \\
\hline Hungary & 39.4 & 39.2 & 40.1 \\
\hline Iceland & 93.2 & 161.4 & 138.8 \\
\hline Norway & 113.6 & 188.2 & 201 \\
\hline Poland & 37.1 & 44.3 & 38.3 \\
\hline Romania & 38.9 & 31.6 & 21.7 \\
\hline Sweden & 113.7 & 169.4 & 185.1 \\
\hline Switzerland & 190.7 & 206.7 & 258.8 \\
\hline
\end{tabular}

Source: http://appsso.eurostat.ec.europa.eu/nui/show.do?dataset=prc ppp ind\&lang=en

Switzerland has the highest price levels, for all the services analysed, $91 \%$ above the EU 28 average on water, electricity, gas and other fuels, $106 \%$ above EU average on health and almost $160 \%$ above the EU average on education. In the opposite corner, Bulgaria has the lowest price levels for all services, $70 \%$ below the EU 28 average on water, electricity, gas and other fuels, $73 \%$ below EU average on health and $80 \%$ below the EU average on education.

Romania has some of the lowest price levels among the EU Member States, on the analyzed services, with PLIs of $61 \%$ below the EU 28 average on water, electricity, gas and other fuels, $68 \%$ below the EU average on health, and almost $78 \%$ below the EU average on education.

Price dispersion is much more significant in these three service categories. In general, prices for services tend to show larger differences between countries than prices for products, due to the larger share of employment in services and high wage dispersion between countries. That is why Switzerland has a price level six times higher than Bulgaria on water, electricity, gas and other fuels, seven times higher on health and almost thirteen times higher on education. Sadly Romania is not far from Bulgaria, especially in education where PLIs are only $1,7 \%$ higher than in Bulgaria.

In Figure 4 we can see, graphically, the fluctuation of PLIs in 2015, for the countries analysed above, and the relation between Romania and the EU 28 average. 


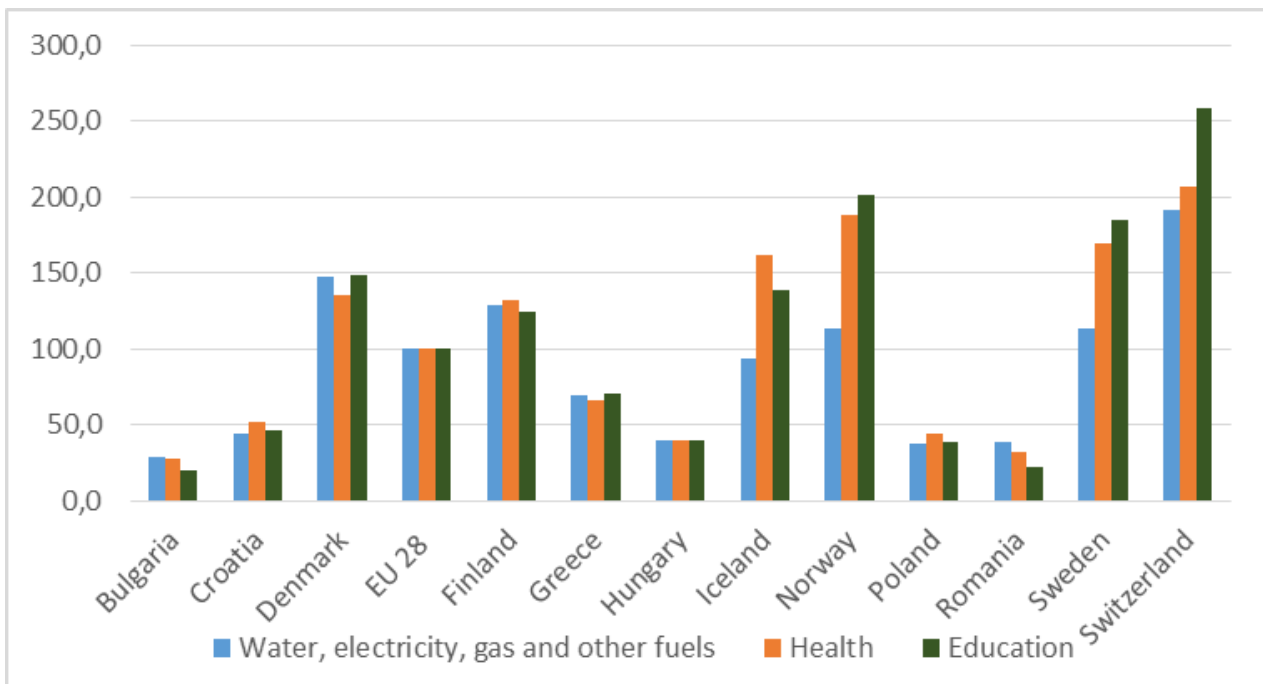

Figure 4: Price level indices for different services in 2015

Source: http://appsso.eurostat.ec.europa.eu/nui/submitViewTableAction.do

\section{Conclusions}

The economic crisis has shown that many European countries are facing fundamental issues and trends that are unsustainable on the long term. The European Union has faced since 2008 a financial and economic crisis. The last economic crisis was caused by lack of regulations, neglect or even violation of regulations in the financial system and particularly in the credit sector, which have gained effects on a global scale (Cismaș, 2013).

The economic crisis in Romania was one of overconsumption. According to the National Institute of Statistic's data, Romania already has a strong consumption growth. Romania's economic growth relies heavily on consumption, which in 2015 made $75 \%$ of GDP, and contributed $4 \%$ to growth of $3.8 \%$. The solution to a crisis of overconsumption is not the undifferentiated consumption stimulation. The solution is more complex. It should start with reducing administrative budget expenditures. The savings can be used for an infrastructure investment plan, because that can create jobs. Also, a plan, for euro adoption, with a clear target, should be taken in consideration; such a plan will increase the external credibility and thus will lower the cost of external financing (Voinea, 2009). Romania has, at this moment, one of the largest economic growths in the EU, $4.3 \%$ in quarter 1 of 2016, but the quality of growth based on consumption - a $20 \%$ in the first four months of the year - does not change much from landscape known for 25 years. We analysed the price level indices for AIC and different products and services for 2015. As shown above there were significant differences in the price levels for consumer goods and services at European level. The Nordic countries and the EFTA states have the highest price levels for most categories of consumer goods and services selected. The lowest PLIs were recorded in south-eastern Europe. Romania is also among the lowest levels in relation to the European average and to other EU Member States (Honţuş, et. al. 2015).

In conclusion, the economic crisis had a strong impact on the European Union. Therefore, the recovery has been very long and slow.

\section{References}

Bartlett, W., Prica, I. (2012). 'The Variable Impact of the Global Economic Crisis in South East Europe', London School of Economics and Political Science, Published by LSEE - 
Research on South Eastern Europe, [Online], Available from: http://www.Ise.ac.uk/europeanInstitute/research/LSEE/PDFs/Publications/LSEE-PAPER-4. pdf. [30.10.2016];

Cismaş, L., Pitorac, R. (2013). 'A new vision on competitiveness within the post-crisis economy. Causes, evolutions and possible innovative solutions to fight against the undesirable effects of the economic crisis', Theoretical and Applied Economics, Vol.XX, no. 10(587), pp. 23-32;

Donath, L., Cismaş, L. (2009). 'The current financial crisis revisited. Causes and remedies', The Romanian Economic Journal, Year XII, no. 31;

Gerstberger, C., Yaneva, D. (2013). 'Statistics in focus 2/2013 - Eurostat', Economy and Finance, [Online],

Available from: http://ec.europa.eu/eurostat/documents/3433488/5585636/KS-SF-13-002-EN.PDF/a4a1ed 61-bac7-4361-a3f0-4252140e1751?version=1.0. [30.10.2016];

Honţuş, A. C., Mărcuţă, A., Tindeche, C., Mărcuţă, L. (2015). 'Impact Of The Economic Crisis On European Union During 2008 - 2015 Period', Scientific Papers Series Management, Economic Engineering in Agriculture and Rural Development vol. 15, [Online], Available from: http://managementjournal.usamv.ro/pdf/vol.15 4/Art17.pdf. [02.02.2017] Roubini, N., Mihm, S. (2010). Crisis Economics, A crash course in the future of finance, The Penguin Press, New York;

Voinea, L. (2009). Sfârșitul economiei iluziei, Criză și anticriză. O abordare heterodoxă, Bucuresti: Editura Publica, Ediția 1.

\section{Bio-note}

Doriana Andreea Rămescu is $\mathrm{PhD}$ Student, first year of study, at the Faculty of Economics and Business Administration, West University of Timişoara, Romania, and currently she is working on PhD thesis: „Relation competition - game theory in market structures”.

Nicoleta Sirghi, PhD is Professor PhD habil. of Economics at the Faculty of Economics and Business Administration, West University of Timisoara, Romania. Her current research focuses on applied economics, game theory with applications in economics. She has presented a great number of papers in these fields in scientific journals and conference proceedings (IBIMA International Conference, WSEAS International Conference etc.). She has been a regular referee of papers for International Business Information Management Conference (IBIMA). She has published in the International Journal of Bifurcation and Chaos (IJBC), in the Transformations in Business and Economics (TIBE). 